\title{
Psychological Capital Questionnaire - Short Version (PCQ-12): evidence of Validity of The Brazilian Version
}

\author{
Helder Kamei ${ }^{\top}$ \\ Maria Cristina Ferreira ${ }^{2}$ \\ Felipe Valentini ${ }^{2}$ \\ Mario Fernando Prieto Peres 3,4 \\ Patricia Tobo Kamei $i^{5}$ \\ Bruno Figueiredo Damásio ${ }^{6}$
}

\author{
${ }^{1}$ Natura Innovation and Technology, Department of Sciences of Well-Being, Cajamar, SP, Brazil \\ ${ }^{2}$ Graduate School of Psychology at Universidade Salgado de Oliveira (UNIVERSO), Niterói, RJ, Brazil \\ ${ }^{3}$ Hospital Albert Einstein, Brain Institute, São Paulo, SP, Brazil \\ ${ }^{4}$ University of São Paulo, Clinics Hospital of the Faculty of Medicine (HCFMUSP), São Paulo, SP, Brazil \\ ${ }^{5}$ Natura Innovation and Technology, Department of Sciences of Well-Being, Cajamar, SP, Brazil \\ ${ }^{6}$ Federal University of Rio de Janeiro, Institute of Psychology, Department of Psychometrics, \\ Rio de Janeiro, RJ, Brazil
}

\begin{abstract}
This study aimed to show evidence of validity for the Brazilian short version (12 items) of the Psychological Capital Questionnaire (PCQ-12). Three independent samples participated in the study, totaling 1771 subjects (64.3\% women, $32.9 \%$ men and $2.9 \%$ undeclared), aged $18-79$ years $(\mathrm{M}=38.59, \mathrm{SD}=12.98)$. Confirmatory factor analyses showed acceptable adjustment indices for the four-factor structure (self-efficacy, hope, resilience and optimism) and for a second-order structure with a general factor of psychological capital explaining the four primary factors. Multi-group confirmatory factor analyses found configural, metric and scalar invariance of the measure for the different samples as well as for men and women. Finally, convergent validity analyses found a positive and moderate correlation of PCQ-12 with satisfaction with life and subjective happiness, as well as a negative and moderate correlation with perceived stress and depression.

Keywords: psychological capital; measurement invariance; organizational psychology; PCQ-12; confirmatory factor analysis.
\end{abstract}

\section{Questionário de Capital Psicológico - Versão Reduzida (QCP-12): evidências de Validade da Versão Brasileira}

\section{Resumo}

Esse estudo tem por objetivo apresentar evidências de validade para a versão brasileira reduzida (12 itens) do Questionário de Capital Psicológico (QCP-12). Participaram do estudo três amostras independentes, totalizando 1771 sujeitos (64,3\% mulheres, $32,9 \%$ homens, e 2,9\% não declarados), com idades entre 18 a 79 anos $(M=38,59 ; D P=12,98)$. Análises fatoriais confirmatórias apresentaram índices de ajuste aceitáveis para a estrutura de quatro fatores (autoeficácia, esperança, resiliência e otimismo) correlacionados e para uma estrutura de segunda ordem, com um fator geral de capital psicológico explicando os quatro fatores de primeira ordem. Análises fatoriais confirmatórias multigrupo encontraram invariância configural, métrica e escalar da medida para as diferentes amostras bem como para homens e mulheres. Por fim, análises de validade convergente encontraram correlação positiva e moderada do QCP-12 com a satisfação com a vida e a felicidade subjetiva, e negativa e moderada com o estresse percebido e a depressão.

Palavras-chave: capital psicológico; invariância da medida; psicologia organizacional; QCP-12; análise fatorial confirmatória.

\section{Cuestionário de Capital Psicológico - Versión Reducida (CCP-12). Evidencias de Validez de la Versión Brasileña}

\section{Resumen}

Este estudio tiene como objetivo presentar evidencias de validez de la versión brasileña reducida (12 ítems) del Cuestionario de Capital Psicológico (CCP-12). El estudio incluyó tres muestras independientes, con un total de 1771 individuos (64,3\% mujeres, $32,9 \%$ hombres y 2,9\% no declarados), con edades entre 18 a 79 años $(M=38,59, \mathrm{SD}=12,98)$. El análisis factorial confirmatorio mostró índices de ajuste aceptable para estructura de cuatro factores correlacionados (autoeficacia, esperanza, resiliencia y optimismo) y para una estructura de segundo orden con un factor general de capital psicológico que explica los cuatro factores de primer orden. Análisis factorial confirmatorio multigrupo encontró invariancia configural, métrica y escalar de la medida para las diferentes muestras, tanto para hombres como mujeres. Por fin, análisis de validez convergente encontraron correlación positiva y moderada de CCP-12 de satisfacción con la vida y felicidad subjetiva, y correlación negativa y moderada con el estrés percibido y la depresión.

Palabras-clave: capital psicológico; invariancia de medición; psicología organizacional; CCP-12; análisis factorial confirmatorio. 
During most of the $20^{\text {th }}$ century, Psychology was focused mainly on studying the negative aspects of human functioning, setting the diagnosis and treatment of illnesses and the clarification of deviations, deficiencies and dysfunctions in human cognition as priorities (Luthans, 2002a). The emergence of the Positive Psychology movement brought about changes in this scenario by defending that Psychology should mainly be concerned with the scientific study of the factors that promote people's health and vitality (Luthans, Luthans, \& Avey, 2014).

In the wake of these changes, organizational behavior researchers, traditionally focused on the analysis of phenomena such as stress, burnout, counterproductive behaviors, resistance to change and shortages, problems and dysfunctions in managers and workers (Luthans, 2002a), also started to adopt the premise that research developed in the job context should prioritize the analysis of the employees' potentials and the development of their weak points (Luthans \& Youssef, 2007). In that sense, Luthans (2002b), despite acknowledging that the organizational behavior area's interest in the positive constructs had been ongoing for quite some time, such as organizational justice, satisfaction at work, commitment and organizational citizenship, introduces the expression positive organizational behavior (Luthans, 2002b) to characterize the study of the individual positive potentials that can be measured, developed and managed.

According to Luthans (2002b), to be included in the field of positive organizational behavior, a construct should comply with a number of criteria, which are: possessing solid theoretical and empirical fundamentals; being measurable by means of psychometrically valid tools; being a capacity in the form of a psychological condition, that is, a capacity that can be developed; having a positive impact on the organizational attitudes and behaviors, especially the performance. After applying these four criteria to various positive psychological constructs (such as wisdom, courage, compassion and emotional intelligence), Luthans (2002a; 2002b) concludes that self-efficacy, hope, optimism and resilience were capacities that complied with these criteria and that could consequently be included in the field of positive organizational behavior.

Stajkovic and Luthans (1998) conceptualize self-efficacy applied to the job context as individual beliefs in one's ability to mobilize motivational, cognitive and behavioral resources to successfully execute work tasks. Hence, workers with stronger self-efficacy beliefs pursue success more because they believe that are capable of achieving it.

The theoretical bases of the hope construct derive from the studies by Snyder (2002), who defines it as a positive motivational state, resulting from the determination or energy towards the achievement of one's own targets and the capacity to plan the trajectory needed to achieve those targets, as well as to seek alternative routes towards success in the presence of obstacles. Hope in the job context therefore involves the desire to be successful and the ability to identify and pursue the route that leads to the desired success (Luthans \& Youssef, 2004).

In the context of Positive Psychology, optimism is considered as a trend to maintain positive expectations about the future (Carver \& Scheier, 2005). In that sense, Luthans, Youssef and Avolio (2007) characterize optimism applied to the work sphere as the capacity to objectively assess the situations in a realistic and flexible manner, aiming to decide what can be done or not in each specific situation.

Luthans (2002a) defines resilience applied to the work context as the capacity to recover from adversities or even from challenging positive situations, such as the promotion to a responsible position. People with higher levels of resilience accept the reality more easily, besides adapting more easily to the unexpected changes that happen in their lives (Luthans \& Youssef, 2004).

Despite considering the particularities of the constructs self-efficacy, hope, optimism and resilience, Luthans, Avolio et al. (2007) propose that these four constructs be organized synergistically in a hierarchically superior psychological resource and introduce the expression psychological capital (Psycap) to designate it.

Psychological capital is therefore an individual positive psychological resource, in which the person feels confident (self-efficacy) to put in efforts to succeed at challenging tasks; makes positive attributions (optimism) about present and future success; perseveres towards goals, redirecting the strategies (hope) to achieve them when necessary and, when confronted with problems and adversities, overcomes them (resilience) to attain success (Luthans, Youssef, et al., 2007). The common characteristic underlying the four components of psychological capital is therefore the individual's trend to act as an agent of his environment, with a view to successfully achieving his targets through the positive assessment of the circumstances and his probability of success, bringing him to make 
efforts and pursue to be able to achieve it (Luthans, Avolio et al., 2007).

To assess the psychological capital, Luthans, Avolio et al. (2007) developed the Psychological Capital Questionnaire (PCQ-24), based on items taken from existing instruments with good evidence of validity and precision, which were aimed at measuring self-efficacy (Parker, 1998), hope (Snyder et al., 1996), optimism (Scheier \& Carver, 1985) and resilience (Wagnild \& Young, 1993).

The psychometric properties of the questionnaire were initially investigated in two different studies (Luthans, Avolio et al., 2007), developed in North American samples of business administration students (study 1) and workers from the service sector and high-technology industries (study 2). The goodness of fit indices obtained in the confirmatory factor analyses applied in both studies provided evidence for the second-order model with four first-order dimensions. In addition, the data from the regression analyses in study two confirmed the hypothesis that psychological capital is a better predictor of satisfaction and work performance when compared to each of its four components. The internal consistency ratios, calculated using Cronbach's alpha coefficient, ranged between 0.72 and 0.80 for the hope scale, between 0.66 and 0.72 for the resilience scale, between 0.75 and 0.85 for the self-efficacy scale, between 0.69 and 0.79 for the optimism scale and between 0.88 and 0.89 for the total scale.

Confirmatory analyses developed in further studies (Luthans, Avey, Avolio \& Peterson, 2010), in which various alternative models were tested, also concluded that the model with four distinct factors and one general second-order factor, representing the psychological capital, produced better goodness of fit indices to the data. This model was also confirmed in Italy (Alessandri, Borgogni, Consiglio, \& Mitidieri, 2015), Portugal (Rego, Sousa, Marques, \& Cunha, 2012) and Spain (Azanza, Domínguez, Moriano, \& Molero, 2014), although some items had to be eliminated in the last two countries to achieve good goodness of fit indices. Avey (2014) interpreted these results, in combination with the results of a greater predictive power of the general factor over its components (Luthans, Avolio et al., 2007), as empirical proof that, although the components of psychological capital present distinct properties, they also possess shared variance with a general second-order factor, which is psychological capital.

Nevertheless, other studies developed with the PCQ-24 did not provide evidence in favor of the theoretical model that supported the development of the instrument. In that sense, the study Görgens-Ekermans and Herbert (2013) developed in South Africa only confirmed the model with four independent factors; in the study by Sahoo and Sia (2015), in India, better goodness of fit indices were found for a model with three independent factors (which combined the items resilience and optimism in a single factor), besides indicating the need to eliminate some items; in the study by Rego, Marques, Leal, Sousa and Cunha (2010), in Portugal, it was concluded that the model with the best goodness of fit was the five-factor model, in which the hope scale unfolded into two factors (determination and trajectory planning); in the study by Cheung, Tang and Tang (2011), in China, the best goodness of fit was found for the single-factor model.

The short version of the Psychological Capital Questionnaire (PCQ-12) consists of 12 items taken from the full version, which are also distributed among four subscales: self-efficacy (3 items); hope (4 items); optimism ( 2 items); resilience ( 3 items). One of the first studies to use this version was developed in China by Luthans Avey, Clapp-Smith and Li (2008), although the authors did not test its structure and only calculated the precision of the total score (0.68). The same happened in a subsequent study (Avey et al., 2011) developed in a North American sample.

On the other hand, the studies by Caza, Bagozi, Levy and Caza (2010) in New Zealand and by Rus, Baban, Jesus and Andrei (2012) in Romania offered evidence that supported the four-factor structure of the instrument, represented by one general second-order factor. In the latter study, however, an item had to be reallocated from the hope scale to the self-efficacy scale to obtain a good goodness of fit index. In the study Viseu et al. (2012) developed in Portugal, the model with four correlated factors demonstrated the best adjustment to the data. Likewise, in a recent study on the invariance of the PCQ-12, Wernsing (2014) found, in samples of workers from the same organization in 12 countries, that psycap was best described by a three-factor structure, in which the optimism items were eliminated.

In summary, the different studies cited reveal that no consensus has been reached yet on the internal structure that is most appropriate to describe the PCQ-12 and that cultural differences may be affecting the results obtained thus far (Sahoo \& Sia, 2015). In that sense, the search for additional validity evidence of the Psychological Capital Questionnaire in 
Brazilian samples is justified, which will permit better comparisons between the results of Brazilian studies with that focus and the results of the countless international studies that have been conducted to deepen the construct's nomological network (see Luthans, Youssef-Morgan, \& Avolio, 2015). Based on these considerations, the objective of this study was to present evidence of internal structure validity, internal consistency, convergent validity and invariance by gender, type of sample and age range for the Psychological Capital Questionnaire - Short Version (PCQ-12) in Brazilian samples.

\section{Method}

\section{Participants}

In total, 1771 subjects participated, being 1138 women (64.3\%), 582 men (32.9\%) and 51 (2.9\%) undeclared. Ages ranged between 18 and 79 years $(M=38.59 ; S D=12.98)$, being $300(22.0 \%)$ young people (18 to 29 years), $928(68.1 \%)$ adults (30 to 59 years), 91 (6.7\%) elderly (over 60 years of age) and 43 $(3.2 \%)$ undeclared.

These participants came from three independent studies. The first sample consisted of 759 subjects $(84.2 \%$ women; $10.1 \%$ men and $5.7 \%$ undeclared; average age $=45.01 ; \mathrm{SD}=12.31$ ), sales consultants at a large Brazilian company. In this group, 320 (42.2\%) had some type of full-time job independently from their sales consulting activities; 94 (12.4\%) had some type of part-time job independently from their sales consulting activities; and $345(44.6 \%)$ were sales consultants only.

The second sample consisted of 603 individuals (51.2\% women; $49.8 \%$ men; Mean age $=33.32$; $\mathrm{SD}=$ 8.81) who lived in the State of São Paulo and participated through a home interview by a data collection company. In this sample, $337(55.9 \%)$ had some type of full-time job, 109 (18.1\%) had some type of part-time job and 157 (26\%) had no type of formal job at the time of study.

The third sample consisted of 409 individuals $(51.1 \%$ men; mean age $=35.54 ; S D=10.90)$, living in the city of Rio de Janeiro. What the job characteristics are concerned, 105 (25.1\%) worked in education, 65 $(15.5 \%)$ in the service sector, $65(15.5 \%)$ in the industry, $48(11.5 \%)$ in commerce, $43(10.3 \%)$ in health, $18(4.3 \%)$ in public safety, $13(3.1 \%)$ in the financial sector, 10 $(2.4 \%)$ worked in the military area, $9(2.1 \%)$ in research and $43(10.6 \%)$ did not indicate their profession. It should be highlighted that all ethical procedures for research involving human beings were guaranteed.

\section{Instruments}

1. Sociodemographic questionnaire: this instrument was intended to survey sociodemographic indicators such as sex, age, income, education, besides occupational information such as type of work and time on the job.

2. Psychological Capital Questionnaire (12 items; PCQ-12): Short version of the Psychological Capital Questionnaire (PCQ-24) (Luthans, Youssef et al., 2007, Brazilian version adapted by Ferreira et al., 2013). The PCQ-12 consists of 12 items, answered on a six-point Likert scale ranging from 1 (I strongly disagree) to 6 (I strongly agree). The original structure of the scale proposed four factors, which are: hope (four items), self-efficacy (three items), resilience (three items) and optimism (two items).

3. Satisfaction with Life Scale (Diener, Emmons, Larsen, \& Griffin, 1985, adapted by Gouveia, Milfont, Fonseca, \& Coelho, 2009): A five-item instrument, answered on a seven-point Likert scale (1 - I completely disagree to 7 - I completely agree), which assesses the levels of satisfaction with level based on the subject's own perception. In this study, the scale presented an adequate internal consistency (alpha reliability) $(\alpha=0.90)$.

4. Subjective Happiness Scale: (Lyubomirsky \& Lepper, 1999, adapted by Damásio, Zanon, \& Koller, 2014): An instrument that assesses the levels of subjective happiness based on the subjects' own perception. The instrument consists of four items, answered in different types of seven-point scales. In this study, the scale presented an adequate internal consistency (alpha reliability) $(\alpha=0.73)$.

5. Perceived Stress Scale (Cohen, Karmack, \& Mermelsteinm, 1983, adapted by Reis, Hino, \& Rodriguez, 2010): The instrument consists of 10 items, being six positive and four negative, and assesses the perceived stress construct through a one-factor dimension. The items are answered on a Likert frequency scale ranging from never (0) to always (4). In this study, the scale presented an adequate internal consistency (alpha reliability) $(\alpha=0.79)$.

6. Patient Health Questionnaire (PHQ-9; Kroenke, Spitzer, \& Williams, 2001, adapted by Fraguas Jr. et al., 2006): The PHQ-9 is a nine-item instrument 
that assesses the presence of each of the symptoms of a major depression episode described in the Diagnostic and Statistical Manual of Mental Disorders (DSM-IV). The questionnaire is answered on a Likert scale ranging from never (0) to almost every day (3), respectively. In this study, the scale presented an adequate internal consistency (alpha reliability) $(\alpha=0.89)$.

\section{Data Analysis Procedures}

To assess the dimensional structure of the PCQ12, confirmatory factor analyses (CFA) were used through the Robust Maximum Likelihood estimation method, using the total sample $(N=1771)$. This estimation method is useful for variables with non-normal distribution, and was used as the sample did not present multivariate normality for all items. Three concurrent models were tested: 1) one-factor model; 2) model with four correlated factors; 3) second-order model with four factors, explained by a higher dimension (Psychological Capital). The goodness of fit indices used to assess the adequacy of the models were: Comparative Fit Index (CFI), Tucker-Lewis Index (TLI), Root mean-square error of approximation (RMSEA) and the Standardized Root-Mean Residual (SRMR). According to the guidelines used (Brown, 2006), CFI and TLI coefficients should be superior to 0.90 , preferably to 0.95; SRMR coefficients should be inferior to 0.10 , and RMSEA coefficients should be inferior (0.08), with a confidence interval below 0.10 .

Next, three multigroup confirmatory factor analyses (MGCFA) were executed to investigate the invariance of the measure for different groups, that is: independent samples (sample $1, n=759$; sample $2, n=$ 603; sample 3, $n=409$ ), sex (male, $n=582$ and female, $n=1138)$ and age groups: young (18 to 29 years, $n=$ 490); adults (30 to 59 years, $n=1134$ ); elderly (over 60 years of age, $n=104)$. The separation of the groups into the above age ranges followed the criteria of the IBGE (IBGE, 2010). The objective of the multigroup analyses was to investigate to what extent the PCQ-12 could be considered an equivalent instrument for both independent samples, and also for men, women, young people, adults and elderly.

The MGCFA assessed the invariance of the PCQ-12 through three different models (Damásio, 2013): Model 1 (unrestricted model/configural invariance) assessed to what extent the factor structure of the scale was acceptable for the groups assessed. If the model was not supported, then the instrument structure cannot be considered equivalent for the different groups. Model 2 (equality of factor loadings/ metric invariance) investigated to what extent the factor loading of the items would be equivalent for the different groups. This model investigates the equivalent importance of the items in the calculation of the factor score. Model 3 (equality of intercepts/scalar invariance) investigates to what extent the intercepts of the items are equivalent for the different groups. Evidences of configural, metric and scalar invariance guarantee that the scale can be used for different subgroups without biasing the final scores, therefore permitting intergroup comparisons (Chen, 2008; Damásio, 2013; Sass, 2011).

The fit indices of model 1 (configural invariance) were investigated by means of the Comparative Fit Index (CFI), Tucker-Lewis Index (TLI), Root meansquare error of approximation (RMSEA) and the Standardized Root-Mean Residual (SRMR). The cutoff points to interpret the indices are the same as mentioned earlier. To investigate the invariance of the measure, a hierarchical procedure was used, in which each model tested was compared with the previous, less restrictive model (Schmitt \& Kuljanin, 2008). The test of difference of the CFI $(\triangle \mathrm{CFI})$ was used as a criterion to assess the invariance of the measure (Cheung $\&$ Rensvold, 2002). Differences $>0.01$ in the CFI indices $(\Delta \mathrm{CFI}>0.01)$ between the model tested and the previous model indicate the non-equivalence of the parameter assessed for the different groups (for further information, see Damásio, 2013).

Finally, to enhance the validity evidence of the PCQ-12, the convergent validity of the questionnaire was investigated using different correlated psychological constructs. Thus, the PCQ was correlated (Spearman correlations) with the constructs satisfaction with life, subjective happiness, perceived stress and depression (samples 1 and 2). Moderate and positive correlations are expected between the PCQ-12 (general factor and subdimensions) and satisfaction with life and subjective happiness, and moderate and negative correlations between the PCQ-12 (general factor and subdimensions) and perceived stress and depression.

\section{Results}

\section{Internal structure of the PCQ}

Using the total sample, three concurrent models were mutually compared. As demonstrated in Table 1, the single-factor model does not present acceptable fit levels. The models with four correlated factors and the 
Table 1.

Goodness of Fit Indices of Different Models of the Psychological Capital Questionnaire (PCQ-12)

\begin{tabular}{lcccc}
\hline \multirow{2}{*}{ PCQ-12 } & \multicolumn{4}{c}{ Goodness of Fit Indices } \\
\cline { 2 - 5 } & CFI & TLI & SRMR & RMSEA (90\% C.I) \\
\hline Models & & & 0.06 & $0.115(0.110-0.120)$ \\
$\quad$ Single factor & 0.81 & 0.77 & 0.040 & $0.060(0.054-0.066)$ \\
$\quad$ Four correlated factors & 0.95 & 0.94 & 0.040 & $0.059(0.054-0.065)$ \\
$\quad$ Second order & 0.95 & 0.94 & &
\end{tabular}

model of second-order (Psychological Capital) present adequate and virtually identical fit levels.

Based on these results, we chose to work with the second-order model. This choice was due to the fact that, by calculating the factor scores, both the scores of the individual factors (self-efficacy, hope, resilience and optimism) and the scores of the second-order factor "Psychological Capital" can be calculated. Figure 1 presents the structure and factor loadings of the model adopted.

Based on the chosen model, the invariance of the scale was tested for the three independent sample, as well as for gender (men and women) and for the different age groups (young people, adults and elderly). The results (see Table 2) demonstrate the PCQ-12's measuring invariance for the three independent samples, as well as for men and women and young people, adults and elderly.

Relations between the Psychological Capital Questionnaire and External Variables

To assess the convergent validity of the PCQ, its general factor and subscales, they were correlated with the scores of other psychological constructs: satisfaction with life (SWLS), subjective happiness (SHS), self-efficacy (SE), and perceived stress (PSS). The results are displayed in Table 3 . As shown, the general scale and the subscales of the PCQ-12 presented moderate positive correlations with satisfaction with life, subjective happiness, as well as moderate negative correlations with depression and perceived stress.

\section{Discussion}

Initially, we aimed to evidence the dimensionality of the Psychological Capital Questionnaire (PCQ-12). Based on earlier studies (e.g., Avey et al., 2011; Caza et al., 2010; Luthans et al., 2008; Rus et al., 2012; Viseu

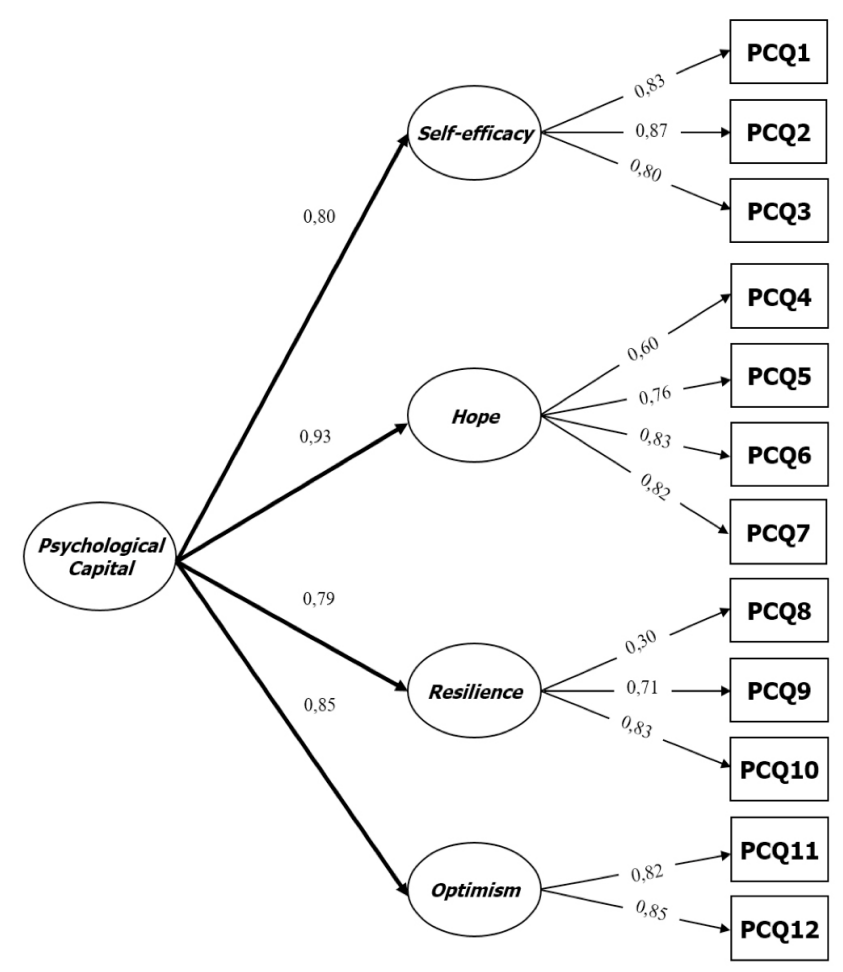

Figure 1. Second-order structure of Psychological Capital Questionnaire (PCQ-12).

et al., 2012), three concurrent models were assessed: a single-factor model, a model with four related factors and a second-order model with four first-order factors. The confirmatory factor analysis presented inadequate fit levels for the single-factor structure, while the four-factor and second-order models were found plausible, with similar fit levels. Therefore, we chose to apply the second-order model in the study because, as mentioned, it permits calculating the factor scores for the general dimension (psychological capital) and for the specific dimensions (hope, self-efficacy, resilience and optimism). It is important to highlight, however, 
Table 2.

Multigroup Confirmatory Factorial Analyses of the Psychological Capital Questionnaire (PCQ-12), Second Order Model

\begin{tabular}{lccccc}
\hline \multirow{2}{*}{ Groups } & \multicolumn{5}{c}{ Goodness of Fit Indices } \\
\cline { 2 - 6 } & CFI & TLI & SRMR & RMSEA $(90 \%$ C.I $)$ & $\Delta$ CFI \\
\hline $\begin{array}{l}\text { Independent samples } \\
\quad \text { Configural invariance }\end{array}$ & 0.953 & 0.936 & 0.044 & $0.062(0.056-0.068)$ & - \\
$\quad \begin{array}{l}\text { Metric invariance } \\
\quad \text { Scalar invariance }\end{array}$ & 0.952 & 0.939 & 0.050 & $0.060(0.054-0.066)$ & 0.001 \\
\hline Sex & 0.948 & 0.938 & 0.050 & $0.060(0.055-0.065)$ & 0.004 \\
$\quad$ Configural invariance & 0.948 & 0.929 & 0.045 & $0.065(0.058-0.071)$ & - \\
$\quad$ Metric invariance & 0.948 & 0.934 & 0.046 & $0.062(0.056-0.068)$ & 0.00 \\
$\quad$ Scalar invariance & 0.942 & 0.931 & 0.048 & $0.063(0.058-0.069)$ & 0.006 \\
\hline Age & & & & & - \\
$\quad$ Configural invariance & 0.953 & 0.936 & 0.044 & $0.065(0.058-0.071)$ & - \\
$\quad \begin{array}{l}\text { Metric invariance } \\
\text { Scalar invariance }\end{array}$ & 0.953 & 0.942 & 0.048 & $0.061(0.055-0.067)$ & 0.000 \\
$\quad$ & 0.947 & 0.940 & 0.052 & $0.063(0.057-0.068)$ & 0.006 \\
\hline
\end{tabular}

Table 3.

Correlations between Psychological Capital Questionnaire and External Constructs

\begin{tabular}{|c|c|c|c|c|c|}
\hline \multirow{2}{*}{$\begin{array}{c}\text { External } \\
\text { Constructs }\end{array}$} & \multicolumn{5}{|c|}{ Psychological Capital Questionnaire (PCQ-12) } \\
\hline & PCQ Total & PCQ SE & PCQ HOP & PCQ RES & PCQ OPT \\
\hline SL & $0.57 * *$ & $0.49 * *$ & $0.58^{* *}$ & $0.47 * *$ & $0.53 * *$ \\
\hline $\mathrm{SH}$ & $0.53^{* *}$ & $0.50^{* *}$ & $0.51 * *$ & $0.43^{* *}$ & $0.52 * *$ \\
\hline PS & $-0.48^{* *}$ & $-0.46^{* *}$ & $-0.46^{* *}$ & $-0.41 * *$ & $-0.47 * *$ \\
\hline PHQ-9 & $-0.44 * *$ & $-0.41 * *$ & $-0.42^{* *}$ & $-0.36 * *$ & $-0.42 * *$ \\
\hline
\end{tabular}

Obs.: ** $p<0.001$; PCQ Total - Factor scores of 'Psychological Capital' in the second-order dimension; PCQ SE - self-efficacy; PCQ HOP - hope; PCQ RES - resilience; PCQ OPT - optimism; SL = satisfaction with life; SH = subjective happiness; PS = Perceived Stress; - PHQ-9 - depression.

that the factor score of the general dimension (Psychological Capital) can only be calculated after modeling the other four specific dimensions. In other words, the construct "Psychological Capital" seems to represent a higher second-order dimension that encompasses the specific constructs, in line with Luthans, Avolio, et al. (2007). In any case, it should be kept in mind that the mere sum of the items, or the calculation of the factor score of the single-dimension instrument, can provide biased estimates of the subjects' levels of psycap. Hence, we suggest that future researchers estimate the participants' scores using structural equations modeling, respecting the model found.
As notice, item 8 of the Resilience factor presented a considerably lower factor loading than the other items (item 8, "At work, I am able to do things without anyone's help", factor loading $=0.33$ ). Possible explanations for the fact that this item obtained a loading below the others can be raised. First, few people may be able to fully execute their job without needing anyone's help these days. In addition, the mutual exchange of information and favors among colleagues may be desirable, helping one another to accomplish their demands, which could be characterized as social support at work, an important resource for occupational wellbeing (Stansfeld, Shipley, Head, Fuhrer, \& Kivimaki, 2013). 
To test the invariance of the PCQ-12, we tested to what extent the factor structure (configural invariance) and factor loading (metric invariance) and the item intercepts (scalar invariance) were similar for different samples. The results suggested that the PCQ-12 was compatible among samples 1, 2 and 3 , and also for men and women and young people, adults and elderly. These results are important for the PCQ-12, as they demonstrate that the instrument can be used in a wide range of samples and that these samples can be mutually compared in an unbiased manner (Sass, 2011).

What the validity evidence based on external measures (AERA, APA, \& NMCE, 2014) is concerned, the PCQ-12 presented significant correlations of a magnitude and in the expected direction, with a range of external variables, which were: satisfaction with life, subjective happiness, perceived stress and depression. Therefore, positive psychological capital is associated with higher rates of wellbeing and lower psychopathology levels. As professional activities tend to occupy a large part of the lifetime in the adult population (Meier, Semmer, \& Gross, 2014), personal characteristics that favor the performance of the job task are expected to positively influence the global indicators of wellbeing and mental health. In organizational terms, intervention strategies that promote the development of psycap can entail positive effects for the workers' wellbeing and should therefore be encouraged, elaborated and implemented.

\section{Final Considerations}

The Psychological Capital Questionnaire (PCQ12) presented satisfactory psychometric properties, demonstrating different evidences of validity in the Brazilian context. The results of the confirmatory factorial analyses and the convergent validity analyses demonstrated that the PCQ-12 can be considered a measure of "Psychological Capital", with specific subdimensions. In addition, it was demonstrated that the scale can be applied to young, adult and elderly men and women and workers with different job affiliations. Researchers who intend to assess the "Psychological Capital" indices should keep in mind that the scores for the general dimension of this instrument should only be calculated after modeling a second-order structure, as the one-dimension structure of the scale (only one general "Psychological Capital" factor was not supported.

Finally, it should be highlighted that this study comes with some limitations. The exclusive use of a convenience sample does not permit the extrapolation of the data to other contexts. In addition, the exclusive use of self-reported instruments may entail implications for the associations found among the different variables, called "effect of the method". Future studies can investigate how other variables, measured in other manners than self-reporting, are associated with the PCQ-12 scores. We hope that future studies using this tool can contribute to the development of knowledge about the importance of psycap in different employment contexts.

\section{References}

American Educational Research Association, American Psychological Association, National Council on Measurement in Education [AERA/APA/ NCME]. (2014). Standards for educational and psychological testing. Washington, DC: American Psychological Association.

Alessandri, G., Borgogni, L., Consiglio, C., \& Mitidieri, G. (2015). Psychometric properties of the Italian version of the Psychological Capital Questionnaire. International Journal of Selection and Assessment, 23(2), 149-159. http:/ / dx.doi.org/10.1111/ijsa.12103

Avey, J. B. (2014). The left side of psychological capital: New evidence on the antecedents of psycap. Journal of LeadershipandOrganizationalStudies, 21(2), 141-149. http://dx.doi.org/10.1177/1548051813515516

Avey, J. B., Reichard, R. S., Luthans, F., \& Mhatre, K. H. (2011). Meta-analysis of the impact of positive psychological capital on employee attitudes, behaviors, and performance. Human Resource Development Quarterly, 22(2), 127-152. http://dx.doi. org/10.1002/hrdq.20070

Azanza, G., Domínguez, A. J., Moriano, J. A., \& Molero, F. J. (2014). Capital psicológico positivo: Validación del cuestionario PCQ en España. Anales de Psicología, 30(1), 294-301. http://dx.doi.org/10.6018/ analesps.30.1.153631

Brown, T. A. (2006). Confirmatory factor analysis for applied research. New York: The Guilford Press. 
Carver, C. S., \& Scheier, M. S. (2005). Optimism. In C. R. Snyder, \& S. J. Lopez (Eds.), Handbook of positive psychology (pp. 231-243). Oxford, UK: Oxford University Press.

Caza, A., Bagozzi, R. P., Woolley, L., Levy, L., \& Caza, B. B. (2010). Psychological capital and authentic leadership: Measurement, gender, and cultural extension. Asia-Pacific Journal of Business Administration, 2(1), 53-70. http:// dx.doi.org/10.1108/17574321011028972

Chen, F. F. (2008). What happens if we compare chopsticks with forks? The impact of making inappropriate comparisons in cross-cultural research. Journal of Personality and Social Psychology, 95(5), 1005-1018. http://dx.doi.org/10.1037/a0013193.

Cheung, G. W., \& Rensvold, R. B. (2002). Evaluating goodness-of-fit indexes for testing measurement invariance. Structural Equation Modeling, 9(2), 233255. cvbn10.1207/S15328007SEM0902_5

Cheung, F., Tang, K. S., \& Tang, S. (2011). Psychological capital as a moderator between emotional labor, burnout, and job satisfaction among school teachers in China. International Journal of Stress Management, 18(4), 348-371. cvbn10.1037/a0025787

Cohen, S., Karmack. T., \& Mermelsteinm, R. (1983). A global measure of perceived stress. Journal of Health and Social Behavior, 24(4), 385-396. http:// dx.doi.org/10.2307/2136404

Damásio, B. F. (2013). Contribuições da análise fatorial confirmatória multigrupo (AFCMG) na avaliação de invariância de instrumentos psicométricos. PsicoUSF, 18(2), 211-220. http://dx.doi.org/10.1590/ S1413-82712013000200005.

Damásio, B. F., Zanon, C., \& Koller, S. H. (2014). Validation and psychometric properties of the Brazilian version of the Subjective Happiness Scale. Universitas Psychologica, 13(1). http://dx.doi.org/10.11144/ Javeriana.UPSY13-1.vppb

Diener, E., Emmons, R. A., Larsen, R. J., \& Griffin, S. (1985). The Satisfaction with Life Scale. Journal of Personality Assessment, 49(1), 71-75. http://dx.doi. org/10.1207/s15327752jpa4901_13

Ferreira, M. C., Chinelato, R. S. C., David, L. M., Novaes, W. P., Silva, J. T. M., \& Leonardo. M. G. L. (2013). Validação convergente da Escala de Capital Psicológico Positivo. In: VI Congresso Brasileiro de Avaliação Psicológica, 2013, Maceió. Anais do VI Congresso Brasileiro de Avaliação Psicológica. Itatiba: IBAP.

Fraguas Jr., R., Gonsalves Henriques Jr., S., De Lucia, M., Iosifescu, D., Schwartz, F., Rossimenezes, P., ..., \& Martins, M. A. (2006). The detection of depression in medical setting: A study with PRIME-MD. Journal of Affective Disorders, 91(1), 11-17. http:// dx.doi.org/10.1016/j.jad.2005.12.003

Görgens-Ekermans, G., \& Herbert, M. (2013). Psychological capital: Internal and external validity of the Psychological Capital Questionnaire (PCQ-24) on a South African sample. SA Journal of Industrial Psychology, 39(2), 1-12. cvbn10.4102/ sajip.v39i2.1131

Gouveia, V. V., Milfont, T., Fonseca, P. N., \& Coelho, J. A., P. M. (2009). Life satisfaction in Brazil: Testing the psychometric properties of the Satisfaction With Life Scale (SWLS) in five Brazilian samples. Social Indicators Research, 90(2), 267-277. http:// dx.doi.org/10.1007/s11205-008-9257-0

Hobfoll, S. E. (2002). Social and psychological resources and adaptation. Review of General Psychology, 6(4), 307-324. http://dx.doi. org/10.1037/1089-2680.6.4.307

Instituto Brasileiro de Geografia e Estatística. (2010). Sintese de Indicadores Sociais [Synthesis of social indicators]. Rio de Janeiro, Brasil: Instituto Brasileiro de Geografia e Estatística.

Kroenke, K., Spitzer, R. L., \& Williams, J. B. W. (2001). The PHQ-9: Validity of a brief depression severity measure. Journal of General Internal Medicine, 16(9), 606-613. http://dx.doi. org/10.1046/j.1525-1497.2001.016009606.x

Luthans, F. (2002a). The need for and meaning of positive organizational behavior. Journal of Organizational Behavior, 23(6), 695-706. http://dx.doi. org/10.1002/job.165

Luthans, F. (2002b). Positive organizational behavior: Developing and managing psychological strengths. Academy of Management Executive, 16(1), 57-72. http://dx.doi.org/10.5465/AME.2002.6640181

Luthans, F., Avey, J. B., Avolio, B. J., \& Peterson, S. J. (2010). The development and resulting performance impact of positive psychological capital. 
Human Resource Development Quarterly, 21(1), 41-67. http://dx.doi.org/10.1002/hrdq.20034

Luthans, F., Avey, J. B., Clapp-Smith, R., \& Li, W. (2008). More evidence on the value of Chinese workers' psychological capital: A potentially unlimited competitive resource? International Journal of Human Resource Management, 19(5), 818-827. http:/ / dx.doi. org/10.1080/09585190801991194

Luthans, F., Avolio, B. J., Avey, J. B., \& Norman, S. M. (2007). Positive psychological capital: Measurement and relationship with performance and satisfaction. Personnel Psychology, 60(3), 541-572. http:// dx.doi.org/10.1111/j.1744-6570.2007.00083.x

Luthans, B. C., Luthans, K. W., \& Avey, J. B. (2014). Building the leaders of tomorrow: The development of academic psychological capital. Journal of Leadership and Organizational Studies, 21(2), 191-199. http://dx.doi.org/10.1177/1548051813517003

Luthans, F., \& Youssef, C. M. (2004). Human, social, and now positive psychological capital management. Organizational Dynamics, 33(2), 143-160. http://dx.doi.org10.1016/j.orgdyn.2004.01.003

Luthans, F., \& Youssef, C. M. (2007). Emerging positive organizational behavior. Journal of Management, 33(3), 321-349. http://dx.doi. org $/ 10.1177 / 0149206307300814$

Luthans, F., Youssef, C. M., \& Avolio, B. J. (2007). Psychological capital: Developing the human competitive edge. Oxford: Oxford University Press.

Luthans, F., Youssef-Morgan, C. M., \& Avolio, B. J. (2015). Psychological capital and beyond. Oxford, MS: Oxford University Press.

Lyubomirsky, S., \& Lepper, H. S. (1999). A measure of subjective happiness: Preliminary reliability and construct validation Social Indicators Research, 46(1), 137-155. doi:10.1023/A:1006824100041

Meier, L. L., Semmer, N. K., \& Gross, S. (2014). The effect of conflict at work on well-being: Depressive symptoms as a vulnerability factor. Work \& Stress, 28(1), 31-48. http://doi.org/10.1080/02678373.2 013.876691

Parker S. (1998). Enhancing role-breadth self efficacy: The roles of job enrichment and other organizational interventions. Journal of Applied Psychology, 83(6), 835-852. http://dx.doi. org/10.1037/0021-9010.83.6.835
Rego, A., Marques, C., Leal, S., Sousa, F., \& Cunha, M. P. (2010). Psychological capital and performance of Portuguese civil servants: Exploring neutralizers in the context of an appraisal system. International Journal of Human Resource Management, 21(9), 15311552. http://dx.doi.org/10.1080/09585192.2010. 488459

Rego, A., Sousa, F., Marques, C., \& Cunha, M. P. (2012). Authentic leadership promoting employees' psychological capital and creativity. Journal of Business Research, 65, 429-437. http://dx.doi. org/10.1016/j.jbusres.2011.10.003

Reis, R. R., Hino, A. A. F., \& Rodriguez, C. R. (2010). Perceived Stress Scale: Reliability and validity study in Brazil. Journal of Health Psychology, 15(1), 107-114. http://dx.doi.org/10.1177/1359105309346343

Rus, C. L., Baban, A., Jesus, S. N., \& Andrei, D. (2012). An analysis of the psychometric properties of the Psychological Capital Questionnaire-12. Journal of Education Sciences and Psychology, 1(2), 110-122.

Sahoo, B. C., \& Sia, S. K. (2015). Psychological capital and organisational commitment: Nature, structure and relationship in an Indian sample. Asia-Pacific Journal of Management Research and Innovation, 11(3), 230-244. http://dx.doi. org/10.1177/2319510X15588386

Sass, D. A. (2011). Testing measurement invariance and comparing latent factor means within a confirmatory factor analysis framework. Journal of Psychoeducational Assessment, 29(4), 347-363. http:/ / dx.doi.org/10.1177/0734282911406661

Scheier, M. F., \& Carver, C. S. (1985). Optimism, coping, and health: Assessment and implications of generalized outcome expectancies. Health Psychology, 4(3), 219-247. Retrieved from http://www. ncbi.nlm.nih.gov/pubmed/4029106

Snyder, C. R., Sympson, S., Ybasco, F., Borders, T., Babyak, M., \& Higgins, R. (1996). Development and validation of the state hope scale. Journal of Personality and Social Psychology, 70(2), 321-335. http://dx.doi.org/10.1037/0022-3514.70.2.321

Snyder, C. R. (2002). Hope theory: Rainbows in the mind. Psychological Inquiry, 13, 249-276. http:// dx.doi.org/10.1207/S15327965PLI1304_01

Stajkovic, A. D., \& Luthans, F. (1998). Self-efficacy and work-related performance: A meta-analysis. 
Psychological Bulletin, 124(2), 240-261. http:/ /dx.doi. org/10.1037/0033-2909.124.2.240

Stansfeld, S. A., Shipley, M. J., Head, J., Fuhrer, R., \& Kivimaki, M. (2013). Work characteristics and personal social support as determinants of subjective well-being. PLoS ONE, 8(11), e81115. http:// dx.doi.org/10.1371/journal.pone.0081115

Wagnild, G. M., \& Young, H. M. (1993). Development and psychometric evaluation of the resiliency scale. Journal of Nursing Management, 1(2), 165-178. Retrieved from: http://www.ncbi.nlm.nih.gov/ pubmed/7850498
Wernsing, T. (2014). Psychological capital: A test of measurement variance across 12 national cultures. Journal of Leadership and Organizational Studies, 21, 179-190. http://dx.doi.org/10.1177/1548051813515924

Viseu, J., Jesus, S. N., Rus, C., Nunes, H., Lobo, P., \& Cara-Linda, I. (2012). Capital psicológico e sua avaliação com o PCQ-12. Estudos Contemporâneos da Subjetividade, 2(1), 4-16. Retrieved from: http:// www.uff.br/periodicoshumanas/index.php/ecos/ article/view/792/666

Recebido em: 21/11/2016

Reformulado em: 26/05/2017

Aprovado em: 03/08/2017 
Sobre os autores:

Helder Kamei. Psychologist. Master in Social and Work Psychology by the University of São Paulo. (USP). Worked as full researcher on Natura Inovação e Tecnologia (Sciences of well-being). Professor of the graduate program of the IPOG and IBC.

E-mail: helderkamei@flowpsicologiapositiva.com

Maria Cristina Ferreira is Doctor in Psychology at Getúlio Vargas Foundation, Brazil. She is a full professor at the Graduate School of Psychology, Salgado de Oliveira University. Her research interests focus on positive organizational behaviour and cross-cultural psychology.

E-mail: mcris@centroin.com.br

Felipe Valentini graduated as Doctor in Psychology at University of Brasília, Brazil. He is an associated professor at the Graduate School of Psychology, Salgado de Oliveira University. His research interests focus in quantitative psychology (especially on item response theory, structural equation modeling, multilevel models, and response bias), psychological assessment, cognitive abilities, learning, and achievement.

E-mail: valentini.felipe@gmail.com

Mario Fernando Prieto Peres. Physicist, Doctor in Neurology by the Federal University of São Paulo (UNIFESP). Post-doctorate by the Thomas Jefferson University, Philadelphia. Is senior researcher from the Hospital Israelita Albert Einstein. Professor of the graduate program in Neurology/Neurosciences - UNIFESP.

E-mail: mariop3r3s@gmail.com

Patrícia Renovato Tobo: Biologist (UFRGS). Master and PhD in Biotechnology by the University of São Paulo. Scientific manager Natura Inovação e Tecnologia (Sciences of well-being). Coordinator of the Applied Research Center on Well-Being and Human Behavior FAPESP/NATURA.

E-mail: patriciatobo@natura.net

Bruno Figueiredo Damásio: Professor of the Institute of Psychology of the Federal University of Rio de Janeiro. Head of the Department of Psychometrics. Professor of the Graduate Program of Psychology. Coordinator of the Laboratory of Psychometrics and Positive Psychology.

E-mail: bf.damasio@gmail.com

Contato com os autores:

Helder Kamei

Alameda Itapecuru, 244, sala 34, Alphaville Industrial

Barueri-SP, Brasil

CEP: 06454-080

Grants: Natura Cosméticos S.A. 